\title{
Reinvigoration of deteriorated corn seed with wetting and drying technique
}

\section{Revigorización de semilla deteriorada de maíz con la técnica de humedecimiento y secado}

ARELLANO-RODRÍGUEZ, Luis Javier†**,RODRÍGUEZ-GUZMÁN，Eduardo，CARRIZALESMEJIA, Norberto and JIMÉNEZ-JIMÉNEZ, José Carlos Universidad de Guadalajara. Departamento de Producción Agrícola. Centro Universitario de Ciencias Biológicas y
Agropecuarias, Camino Ing. Ramón Padilla Sánchez 2100, Nextipac, 44600 Zapopan, Jalisco

ID $1^{\text {st }}$ Autor: Luis Javier, Arellano-Rodríguez / ORC ID: 0000-0002-3188-0245, arXiv Author ID: LuisJavier\#1, CVU CONACYT ID: 65995

ID $1^{\text {st }}$ Coautor: Eduardo, Rodríguez-Guzmán / ORC ID: 0000-0002-4640-7610, Researcher ID Thomson: T-9496-2019, CVU CONACYT ID: 67847

ID $2^{\text {nd }}$ Coautor: Norberto, Carrizales-Mejia / ORC ID: 0000-0003-4358-714X, arXiv Author ID: Norberto5506, CVU CONACYT ID: 255239

ID $3^{\text {rd }}$ Coauthor: José Carlos, Jiménez-Jiménez.

DOI: $10.35429 /$ EJRN.2019.9.5.1.5

Received June 02, 2019; Accepted December 30, 2019

\begin{abstract}
With the objective of reinvigorating damaged corn seed, the technique of wetting and drying the seed with five types of water and 10 imbibition times. Estimating the variables emergency percentage, emergency speed, seedling length and root length, and plant height 30 days emergency. For the variable speed of emergency for imbibition time the highest vigor corresponded to 18 and $12 \mathrm{~h}$, and with an emergency percentage of $62 \%$ higher in $10 \%$ of the control, it was 4,8 and $18 \mathrm{~h}$. In water types for emergency percentage, the highest values were observed in artesian well and Key water. In seedling length with values of 25 to $24 \mathrm{~cm}$ were distilled water $30 \mathrm{~h}$, artesian well $8 \mathrm{~h}$ y $18 \mathrm{~h}$; and the control was 22 $\mathrm{cm}$. In radicle length the highest values corresponded to E. Pure $₫ 24 \mathrm{~h}$ and key water $14 \mathrm{~h}$. For plant height in $8 \mathrm{~h}$ artesian well present a value of 175 $\mathrm{cm}$, and the control with a value of $165 \mathrm{~cm}$.
\end{abstract}

Reinvigoration, Corn, Wetting, Imbibition

\begin{abstract}
Resumen
Con el objetivo de revigorizar semilla de maíz deteriorada, se utilizó la técnica de humedecimiento y secado de semilla con cinco tipos de agua y 10 tiempos de imbibición. Estimando las variables porcentaje de emergencia, velocidad de emergencia, longitud de plántula y longitud de raíz, y altura de planta a los 30 días de emergencia. Para la variable velocidad de emergencia en tiempo de imbibición el vigor más alto correspondió a 18 y $12 \mathrm{~h}$, y con un porcentaje de emergencia de $62 \%$ superior en $10 \%$ del testigo, fue de 4, 8 y $18 \mathrm{~h}$. En tipos de agua para porcentaje de emergencia los valores más altos se observaron en agua de la llave y agua de pozo. En longitud de plántula con valores de 25 a $24 \mathrm{~cm}$ se ubicaron el agua destilada $30 \mathrm{~h}$, agua de pozo $8 \mathrm{~h}$ y 18h; y el testigo se ubicó con $22 \mathrm{~cm}$. En longitud de radícula los valores más altos correspondieron al $\mathrm{E}$. Pura ${ }^{\circledR} 24 \mathrm{~h}$ y agua de la llave $14 \mathrm{~h}$. Para altura de planta en agua de pozo $8 \mathrm{~h}$ presento un valor de 175 $\mathrm{cm}$, y el testigo con un valor de $165 \mathrm{~cm}$.
\end{abstract}

Revigorización, Maíz, Humedecimiento, Imbibición

Citation: ARELLANO-RODRÍGUEZ, Luis Javier, RODRÍGUEZ-GUZMÁN, Eduardo, CARRIZALES-MEJIA, Norberto and JIMÉNEZ-JIMÉNEZ, José Carlos. Reinvigoration of deteriorated corn seed with wetting and drying technique. ECORFAN Journal-Republic of Nicaragua. 2019. 5-9: 1-5

\footnotetext{
* Correspondence to Author (email: javier.arellano@academicos.udg.mx)

$\dagger$ Researcher contributing as first author.
} 


\section{Introduction}

A quality seed is characterized by its high percentage of germination and vigor, which ensures the emergence in the field and the success in crop productivity; FAO recognizes that seeds occupy a central place in the agricultural development process: the improvement of seed quality is a fundamental factor in increasing the crop yield potential and is one of the most economical and efficient means to improve Agricultural production and productivity (FAO, 2006). The storage time of the seed and the high temperatures and high humidity prevailing during its conservation favor its deterioration. Studies carried out in soybean (Moreano et al., 2011) allow to maintain that the reduction in the physiological quality of the seed is a consequence of common problems such as aging and deterioration.

To counteract the negative effects of the seed deterioration process, various treatments have been used with partial success in various species, such as chemical treatment before sowing (pre-sowing) (Grzesik and Janas, 2014) and pre-hydration ( pre-soaking) with water or with growth regulators this to improve germination capacity and vigor (Butola and Badola, 2004; Herrera et al., 2011). Seed germination can be defined as a series of metabolic and morphogenetic processes, which result in the transformation of the embryo into a seedling capable of becoming an adult plant. In the germination of the seed, sequential and synchronized processes occur and are recognized in such a way that anabolic and catabolic processes take place simultaneously. (Coll et al., 1995).

During the germination process the stage known as imbibition is presented. The imbibition is the process of water intake by the seed (Moreno et al., 2006). This occurs by immersing the seeds in osmotic solutions or in certain amounts of water for a certain period of time. The imbibition allows a greater number of seeds to quickly reach the same level of humidity and activate the metabolic apparatus related to the pre-germination process (Burgas and Powell, 1984). In this way, a physiological path known to improve the germinative behavior of many species of agricultural interest is the pregerminative treatments of wetting and drying of the seeds.
Which has proven to be efficient to reinvigorate aged seeds, accelerate and increase the germination and yields of plants, both under optimal and adverse ecological conditions (Bradford, 1986). Water is essential for the rehydration of the seeds. The amount of water absorbed by an imbibed seed depends on a number of factors, such as the size of the seed, permeability of the testa and the age of the seed. In absolute terms, water absorption is relatively small and can often not exceed 2 to 3 times the dry weight of the seed. For the establishment and subsequent development of the seedling, a greater and sustained water supply is required. Consider: 1) the water relations of the seed and 2) the relationship between the seed and its substrate (Bewley and Black 1994; Moreno et al., 2006). Thus, in the present study, there was a deteriorated corn seed, and to reinvigorate it, the following objective was raised.:

\section{Objective}

Reinvigorate damaged corn seed with the use of the seed wetting and drying technique using five types of water and 10 imbibition times.

\section{Materials and methods}

The experiment was carried out in experimental fields of the facilities of the University Center of Biological and Agricultural Sciences, in Las Agujas, Zapopan, Jalisco. A variety of yellow corn was used with an initial germination of $50 \%$. And five types of water: 1) Ciel® Water $(\mathrm{EC}=0.6 \mathrm{dS} \mathrm{m}-1$ and $\mathrm{pH}=5.8), 2)$ Epura ${ }^{\circledR}$ Water $(\mathrm{EC}=0.4 \mathrm{dS} \mathrm{m}-1$ and $\mathrm{pH}=7.3), 3)$ Tap water $(\mathrm{EC}=0.9 \mathrm{dS} \mathrm{m}-1$ and $\mathrm{pH}=7.6)$, 4) Distilled water $(\mathrm{EC}=0.1 \mathrm{dS} \mathrm{m}-1$ and $\mathrm{pH}=8.5)$, and 5) Deep well water $(\mathrm{EC}=3.0 \mathrm{dS} \mathrm{m}-1$ and $\mathrm{pH}=6.3$ ). The seed was imbibed in each type of water at times of 4, 8, 12, 18, 24, 30, 38, 44, 50 and $60 \mathrm{~h}$ respectively. After each imbibition period, the seed was dried for five days at room temperature and / in the shade.

The Imbibition Cup (IT) variable was created as a result of the difference between the initial weight and final weight (after each imbibition period) With the initial electrical conductivity (EC) and $\mathrm{pH}$ data and at each imbibition time the effects of these variables on the imbibition rate. The 51 treatments derived from water types (5) and times (10), plus the control (unimbibed seed) were sown under field conditions in three repetitions of 100 seeds each. 
Evaluating the emergency speed (VE) (Maguire, 1962). Data were taken daily of the number of seedlings emerged per plot / day and ended 15 days after planting. In this same test, the number of emerged seeds/plots was counted, resulting in the emergency percentage variable (\% MS). On the other hand, the 51 treatments were sown at 25 seeds / plot every $10 \mathrm{~cm}$ and in three repetitions; evaluating the variables seedling length (LP), root length (LR), and plant height 30 days after the emergency (AP). The experiments were placed under a completely randomized block design, the results were processed with the SAS 2009 statistical package through analysis of variance, and Tukey test at $5 \%$ probability.

\section{Results and Discussion}

In the Imbibition Cup variable, no significant differences were obtained with the five types of water, but it did show significant differences $(\alpha \leq 0.05)$ in imbibition times. In the variables electrical conductivity and $\mathrm{pH}$, significant differences were found between types of water and imbibition times. In Table 1 , it can be seen that at $60 \mathrm{~h}$ the highest IR and EC and the lowest $\mathrm{pH}$ were obtained.

\begin{tabular}{|c|c|c|c|c|c|c|}
\hline \multicolumn{4}{|c|}{ Imbibition Time } & \multicolumn{3}{|c|}{ Water Type } \\
\hline \multicolumn{2}{|c|}{ IR } & $\mathrm{EC}$ & $\mathrm{pH}$ & & $\mathrm{EC}$ & $\mathrm{pH}$ \\
\hline $60 \mathrm{~h}$ & $79 a$ & $5.4 \mathrm{a}$ & $3.7 \mathrm{f}$ & CIEL® & $2.4 \mathrm{~b}$ & $4.9 \mathrm{~b}$ \\
\hline $50 \mathrm{~h}$ & $60 \mathrm{~b}$ & $3.9 \mathrm{~b}$ & $3.9 \mathrm{f}$ & EPURA® & $2.1 \mathrm{~b}$ & $4.7 \mathrm{~b}$ \\
\hline $44 \mathrm{~h}$ & $58 \mathrm{~b}$ & $2.6 \mathrm{c}$ & 4.4def & LLAVE & $2.4 \mathrm{~b}$ & $4.5 b$ \\
\hline $24 \mathrm{~h}$ & $52 \mathrm{bc}$ & $2.6 \mathrm{c}$ & $4.9 \mathrm{~cd}$ & DEST & $1.8 \mathrm{~b}$ & $5.5 \mathrm{a}$ \\
\hline $38 \mathrm{~h}$ & $52 \mathrm{bc}$ & $2.5 \mathrm{c}$ & $4.8 \mathrm{~cd}$ & POZO & $4.2 \mathrm{a}$ & $4.8 \mathrm{~b}$ \\
\hline $30 \mathrm{~h}$ & $51 \mathrm{bc}$ & $2.5 \mathrm{c}$ & $4.8 \mathrm{~cd}$ & & & \\
\hline $18 \mathrm{~h}$ & $43 \mathrm{~cd}$ & $2.5 \mathrm{c}$ & 4.4def & & & \\
\hline $12 \mathrm{~h}$ & $40 \mathrm{de}$ & $2.3 \mathrm{~d}$ & $4.7 \mathrm{cde}$ & & & \\
\hline $8 \mathrm{~h}$ & $32 \mathrm{ef}$ & $1.5 \mathrm{~cd}$ & $5.5 \mathrm{bc}$ & & & \\
\hline $4 \mathrm{~h}$ & $24 \mathrm{f}$ & $1.4 \mathrm{~cd}$ & $5.8 \mathrm{~b}$ & & & \\
\hline In & $0.0 \mathrm{~g}$ & $1.0 \mathrm{~d}$ & $7.1 \mathrm{a}$ & & & \\
\hline
\end{tabular}

Where: In = start, IR = Imbibition rate, $\mathrm{EC}=$ Electrical Conductivity. Means with the same letter in each column are statistically equal (Tukey $\alpha \leq 0.05<$ )

Table 1 Comparison of means for the variables of imbibition cup, electrical conductivity and $\mathrm{pH}$, on imbibition time and types of water

Oguntunde and Adebawo (1989), determined the individual water absorption patterns of $\mathrm{cv}$ 'TZPB' corn seeds, local white corn, white and red sorghum types at $30,35,40$ and $45^{\circ} \mathrm{C}$ soaked for 0 to 72 hours. The hydration curves obtained showed that the highest moisture absorption of the seeds of these materials occurred within the first 24 hours, while the maximum water absorption or moisture saturation content occurred after 36 hours, regardless of temperature in soaking.
For water type, the highest EC was presented in the deep well water, and the highest $\mathrm{pH}$ value (5.5) was obtained with distilled water (Table 1). The other treatments followed the same trend. For example, the distilled water at the beginning of the test had the lowest EC values $(0.1 \mathrm{dS} \mathrm{m}-1)$ and the highest $\mathrm{pH}$ value (8.5), ending with values of 1.8 and $5.5 \mathrm{dSm}-1$ respectively at $60 \mathrm{~h}$ of imbibition. The electrical conductivity test is based on the greater or lesser release of leachate by the seeds (ions, sugars, amino acids, among others) to the imbibition medium according to their physiological condition. The damaged seeds or with low physiological potential (less vigor) are those that release more leachate into the environment (greater conductivity), due to the loss of the integrity of cell membranes (Vieira et al., 2002).

In the variable emergency speed (VE); According to the analysis of variance, no significant differences were obtained for water types, but for imbibition times. While for\% EM significant differences were found for times and types of water.

When performing the comparative test of means, the greatest vigor was obtained at $6 \mathrm{pm}$ (14.9), followed by $12,8,4$ and 44 hours respectively. And with lower values next to the control (seed without imbibir) 38 and $30 \mathrm{~h}$ (Graph 1). While the highest emergency percentage was obtained at 4,8 and $18 \mathrm{~h}$, surpassing the witness (50\%) with 62\% emergency (Graph 1).

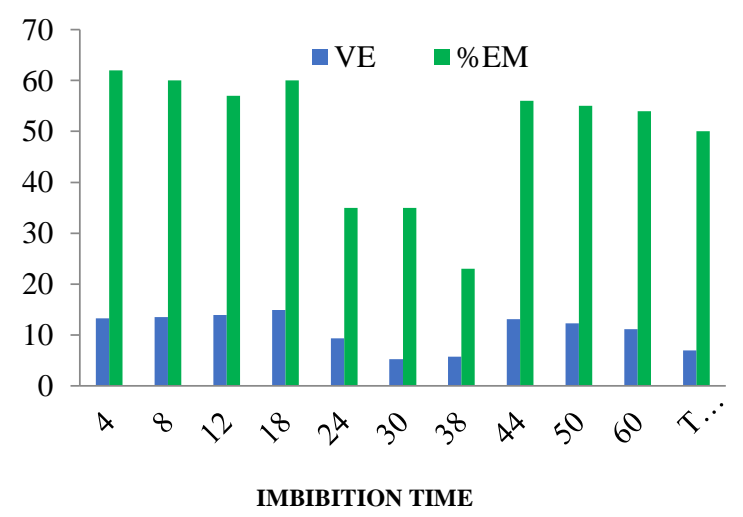

Graphic 1 Behavior of the emergency speed (VE) and emergency percentage (\% EM) variables based on 10 imbibition times

The treatment of $18 \mathrm{~h}$ of imbibition was observed as the one with the highest vigor and with a percentage that exceeded the control by $12 \%$. Greatly favoring the recovery of the damaged seed. 
And it should be noted that the lowest electrical conductivity was observed in the times of 4,8 and $18 \mathrm{~h}$ (Table 1). Times that favored the least amount of leachate in the water, and therefore the least deterioration. The electrical conductivity test (EC) and the $\mathrm{pH}$ test have been proposed to provide estimates of germination and / or vigor of seeds in 24 hours or less (Wilson, 1992). The range of electrical conductivity required for adequate crop growth is between 1.5 to $3.0 \mathrm{dS} \mathrm{m}-1$, depending on the species and the EC of the water (Carrasco and Izquierdo, 1996).

In the comparative test of means, in types of water, it is observed in graph 2, that the lowest vigor was obtained in distilled water, While the highest percentage of emergency (\% MS), was observed with the tap water and the deep well; followed by A. Ciel ${ }^{\circledR}$ and A. EPura ${ }^{\circledR}$ (Graph 2).

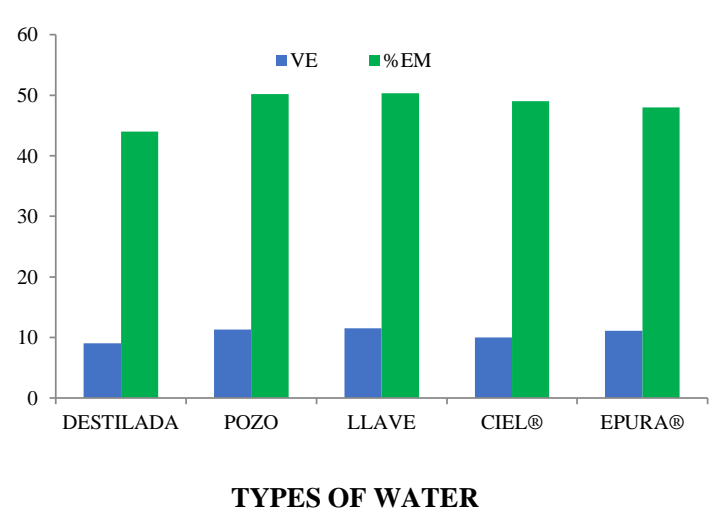

Graphic 2 Behavior of the emergency speed (VE) and emergency percentage (\% $\mathrm{EM})$ variables based on five types of water

For the seedling length variable, greater length was observed in the treatments of distilled water $30 \mathrm{~h}$ and well water of 12,18 and $8 \mathrm{~h}$ respectively and the tap water at $18 \mathrm{~h}$ (Graph 3).

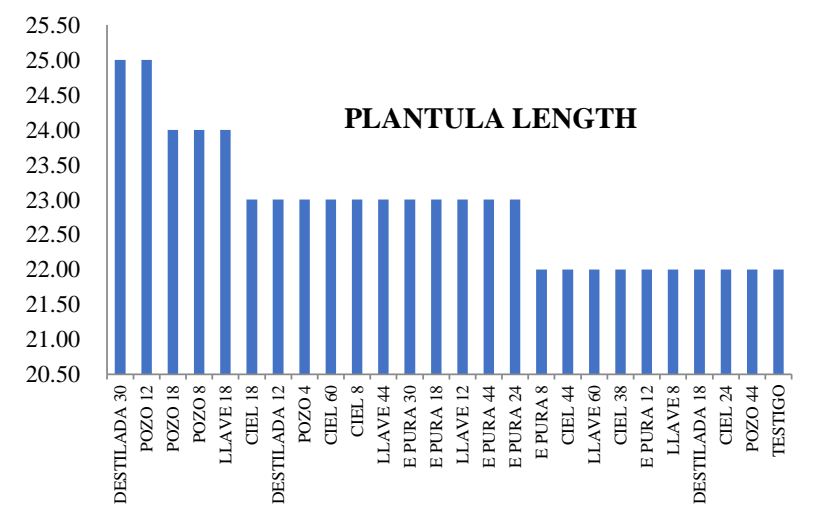

Graphic 3 Behavior of the seedling length variable (LP) in imbibition times and water types
In the variable root length (LR), the treatments that exceeded the behavior of the control (unimbibed seed), and were much higher than the rest: EPura ${ }^{\circledR} 24,38$, and $12 \mathrm{~h}$ respectively. As well as tap water with $24 \mathrm{~h}$ of imbibition (Graph 4).

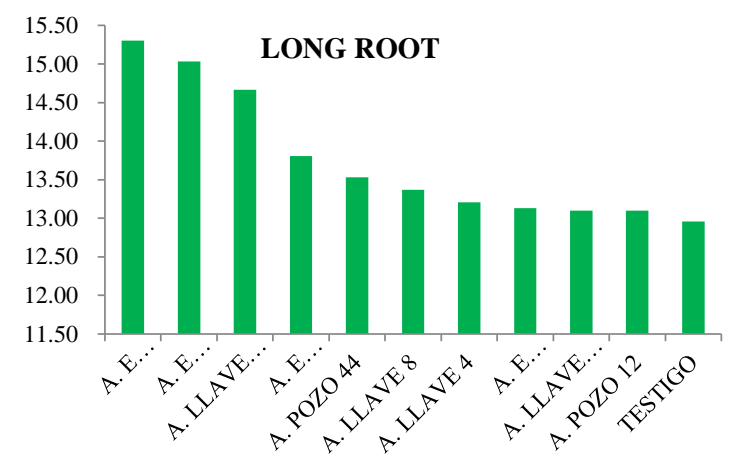

Graphic 4 Behavior of the variable root length (LR) at imbibition times and water types

In the variable plant height, taken 30 days after the emergence of the seedling, only the deep well water treatments 8 and $30 \mathrm{~h}$ respectively and $60 \mathrm{~h}$ distilled water reached a height greater than $175 \mathrm{~cm}$. In the control, a height of $165 \mathrm{~cm}$ higher than the rest of the treatments was observed (Graphic 5).

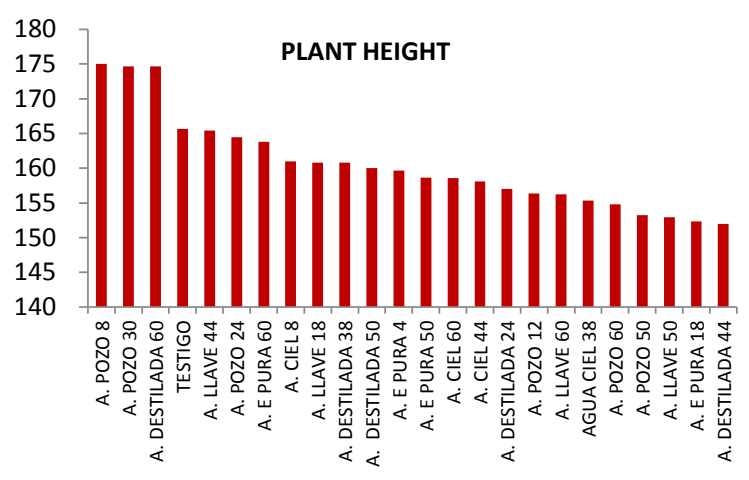

Graphic 5 Behavior of the variable plant height at 30 days after emergence in imbibition times and water types

\section{Conclusions}

In the five types of water the imbibition rate and electrical conductivity were increased as the imbibition periods increased. Otherwise the $\mathrm{pH}$ decreased. For the variable emergency speed at imbibition time, the highest vigor corresponded to 18 and $12 \mathrm{~h}$, and with an emergency percentage greater than $60 \%$ it was 4,8 and 18 h. Favoring these variables with the use of tap water and deep well water. 
25 treatments were superior in seedling length, and 10 treatments obtained the highest values of root length in relation to the control.

There was a significant effect on the plant height variable with the use of water types and imbibition times by showing increases and decreases in height in relation to the control.

\section{References}

Bewley J. D. y M. Black. (1994). Seeds physiology of development and germination. 2nd (Ed.). Plenum Press, New York. 445 p.

Bradford K. J. (1986). Manipulation of seed water relations via osmotic priming to improve germination under stressc onditions. HortScience 2 1:1105-1112

Burgas R. y A. Powell. (1984). Evidence for repair processes in the invigoration of seeds by hydration. Ann. Bot. 53:753-757.

Butola J. S. y K.H. Badola. ( 2004). Effect of pre-sowing treatment on seed germination and seedling vigour in Angelica glauca, a threatened medicinal herb. Curr. Sci. 87:796-799.

Carrasco G. e J. Izquierdo. (1996). La empresa hidropónica de mediana escala: la técnica de la solución nutritiva recirculante ("NFT"). Universidad de Talca (ed.). Talca. pp. 56-90.

Coll J. B., G. N. Rodrigo, B. S. García y R. S. Tamés. (1995). Fisiología vegetal. Madrid. Ediciones Pirámide. 662 p.

FAO. (2006). Sistemas de semillas de calidad declarada. Servicio de Semillas y Recursos Fitogenéticos de la FAO. Ed. Organización de las Naciones Unidas para la Agricultura y la Alimentación Roma. ISBN 92-5-305510-3

Grzesik M. y R. Janas R. (2014). Physiological method for improving seed germination and seedling emergence of root parsley in organic systems. J. Res. Appl. Agric. Eng. 59(3):80-86.

Herrera C. C., G.C. Carrillo, V. A. H. González, J. A. S. Carrillo, V.C.V. Peña, y J. R. N.García. (2011). Tratamientos químicos para recuperar la germinación en semillas de cebolla. Rev. Chapingo Serie Hort. 17:63-72.
Maguire J.D. (1962). Speed of germinationAID in selection and evaluation for seedling emergente and vigor. Crop. Sci. 2: 176-177.

Moreano T., A. Braccini, C. Scapim, F. Krzyzanowski, J. Franca-Neto, y O. Masques. (2011). Changes in the effects of weatering and mechanical damage on soybean seed during storage. Seed Sci \& Tech. 39: 604-611

Moreno F. G., P. Plaza, y S. Magnitskiy. (2006). Efecto de la testa sobre la germinación de semillas de caucho (Hevea brasiliensis Muell.). Agron. Colomb. 24(2):290-295.

Oguntunde A. C. y O. O. Adebawo. (1989). Wateruptake pattern during traditional soaking of cereal grains. Tropical Science 29 (3): 189197.

Vieira R., A. Penariol, D. Perecin y M. Panobianco. (2002). Condutividade elétrica e teor de agua inicial das sementes de soja. Pesquisa Agropecuária Brasileira, 37: 13331338.

Wilson D. (1992). A unified approach to interpretation of single seed conductivity data. Seed Science and Technology. 20: 155-163. 